\title{
Biochemical Particularities in a Pacient with Celiac Disease A case presentation
}

\author{
COSMIN ALEXANDRU CIORA ${ }^{1}$, VLAD DUMITRU BALEANU2*, DRAGOS VIRGIL DAVITOIU ${ }^{3}$, CARMEN PLAISANU ${ }^{4}$ \\ ${ }^{1}$ Carol Davila University of Medicine and Pharmacy, Discipline of Gastroenterology and Hepatology, 8 Eroii Revolutiei Blvd., \\ 050474, Bucharest, Romania \\ ${ }^{2}$ University of Medicine and Pharmacy of Craiova, Surgery Department, Clinical Emergency Hospital Sf. Pantelimon Bucharest, \\ 340-342 Pantelimon Road, 021659, Bucharest, Romania \\ University of Medicine and Pharmacy of Bucharest, Surgery Department, Clinical Emergency Hospital Sf. Pantelimon Bucharest, \\ 340-342 Pantelimon Road, 021659, Bucharest, Romania \\ ${ }^{4}$ Gastroenterology and Hepatology, Fundeni Clinical Institute, 258 Fundeni Str., 022322, Bucharest, Romania
}

Celiac disease is an autoimmune disease with many systemic manifestations and almost no specific symptoms. Report the case of a young woman with abdominal pain (colic type), bloating and up to 10 loose stools (day and night) associated with progressive weight loss that has been diagnosed with celiac disease in the gastroenterology and hepatology department. After full adherence to the gluten-free dietall biochemical abnormalities disappeared and the patient became normoponderal.

Keywords: Celiac Disease, Gastroenterology, Miscarriages

Failure to recognize these symptoms may lead to a delay in the diagnosis, a late disease onset and major long term complications. Once upon a time considered to be a rare disease, the celiac disease is now present in 1/100 persons $[1,2]$. Despite the high prevalence, more than $95 \%$ of the affected individuals remain undiagnosed probably because approximately $38 \%$ of them have asymptomatic disease and the doctors associate their symptoms with other diseases. Classic celiac disease involves the existence of gastrointestinal symptoms or consequences due to malabsorption. It is the most documented form of the disease. Patients have nausea, bloating, tympanites, discomfort, abdominal pain, abnormal stool, usually diarrhea. Classical symptoms include also weight loss despite a normal appetite, more frequent in children, which have failure to thrive. Fatigability and weakness are the result of the low absorption of nutrients in the small intestine and also because of the iron deficiency anemia [3].

\section{Experimental part}

Atypical celiac disease is characterized by the absence of gastrointestinal manifestations or poor gastrointestinal symptoms. The extra intestinal symptoms like iron deficiency anemia, failure to thrive, osteoporosis or infertility are to the fore. Paradoxically, this form of celiac disease is more common than the classic form but because of the absence of gastrointestinal symptoms is often underdiagnosed $[4,5]$.

We will present you the case of a 35 years old female, married for 7 years, 1 children 3 years old. The patient addressed our clinic for the emission of 10 loose stools per day since the last 12 months associated with significant weight loss, about 12 kilograms.

\section{Clinical examination}

Upon admission the patienthad a poor general condition, she was dehydrated, with diffuse abdominal pain, bloating, nausea and vomiting. She denied smoking, alcohol use or drugs. She had a weight of $47 \mathrm{Kg}$ and a height of $165 \mathrm{~cm}$ with a BMI of $17.2 \mathrm{Kg} / \mathrm{m}^{2}$ - underweighted. Her's usual weight was $59 \mathrm{Kg}$. From her personal medical history we noticed two years history of iron deficiency anemia, two spontaneous miscarriage and appendectomy in childhood. Her first period was at the age of 14 . Her periods have always been irregular and she had amenorrhea for the last 6 months. Her family medical history was negative for celiac disease or inflammatory bowel disease.

\section{Laboratory findings}

Her blood panel showed a mild hypochromic microcytic anemia ( $\mathrm{Hb}: 10.5 \mathrm{~g} / \mathrm{dL}, \mathrm{MCV}: 72 \mathrm{fL}, \mathrm{MCHC}: 29 \mathrm{~g} / \mathrm{dL}$ ), serum ferritin $9 \mathrm{ng} / \mathrm{dL}$, transferrin saturation $17 \%$, folate $=2 \mathrm{ng} /$ $\mathrm{mL}$, vitamin B12 $=100 \mathrm{pg} / \mathrm{mL}$. Beside an elevated ASAT and ALAT more than twice the upper limit of normal and VSH $=50 \mathrm{~mm} / \mathrm{hr}$, the rest of the biochemistry panel was within normal values. She was tested negative for hepatitis $B$ and $C$. Also, serology for autoimmune hepatitis and Wilson's disease were negative. Her stool analysis was negative for bacteria and parasites. Fecal calprotectin was also normal. Anti tTG antibodies were positive (102.62 U/ $\mathrm{mL}$ ) and anti gliadin antibodies were positive too.

\section{Endoscopic examination}

The endoscopic examination of the second part of the duodenum revealed flattened folds and a nodular pattern of the mucosa. Six biopsies were taken each with only

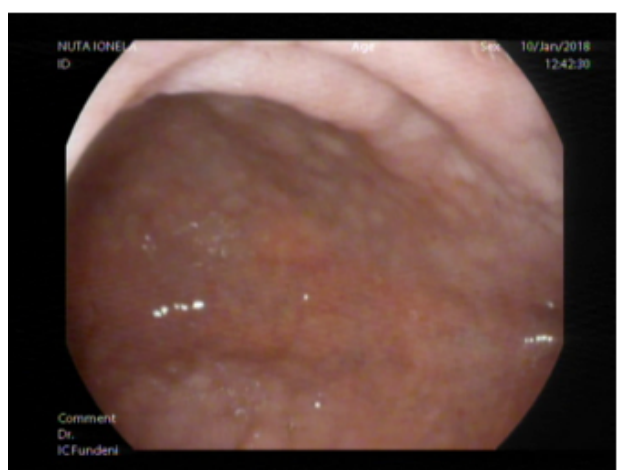

Fig. 1. DII mucosal edema, nodular aspect suggestive of gluten-sentive enteropathy, the absence of Kerckring folds (biopsy)

\footnotetext{
*email: baleanuvlad@gmail.com; Phone: 0040765865886
} 
one passage of the biopsy forceps and they were examined by the histopathology experts from our clinic.

Histopathology examination

Histological lesions consisting with partial villous atrophy, with intraepithelial lymphocytosis suggestive of

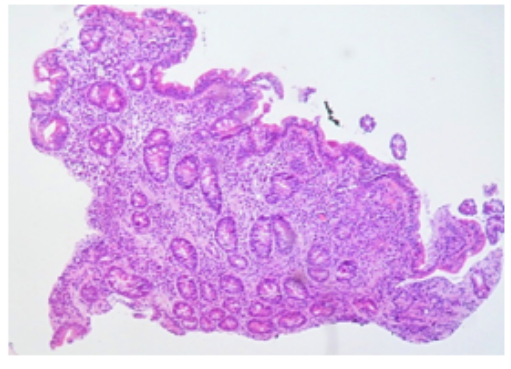

Fig..2

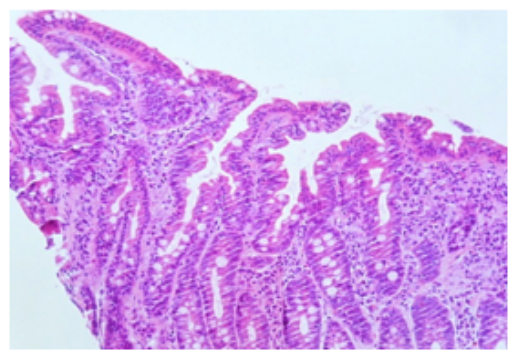

Fig.. 3

gluten-sensitive enteropathy Grade $3 a$ Marsh-Oberhuber (Fig. 2, 3)

\section{Results and discussions}

The patient adheres incompletely to the gluten-free diet for 3 months, obtaining only a slight clinical improvement. All abnormal biochemical markers retained their initial values. After a new reassessment at 6 months of the gluten-free diet, the symptomatology disappears and the normalization of the biochemical tests is obtained.

There are many published clinical trials that suggest a link between celiac disease and infertility [6-10], unexplained iron deficiencyanemia [11,12] and persistent elevations of serum transaminases [ 7]. The most common biochemical changes associated with celiac disease are ferriprive anemia and elevated transaminase values of unknown cause. There are no precise guidelines to establish the risk groups where screening for celiac disease should be recommended. Iron is an importantmicronutrient that may be depleted in celiac disease. Iron deficiency and ferriprive anemia may complicate well-established celiac disease, but may also be the presenting clinical feature in the absence of diarrhea or weight loss. If iron deficiency anemia occurs, it should be thoroughly evaluated, even if celiac disease has been defined since other superimposed causes of iron deficiency anemia may be present. Mostoften, impaired duodenal mucosal uptake of iron is evident since surface absorptive area in the duodenum is reduced, in large part, because celiac disease is an immune-mediated disorder largely focused in the proximal small intestinal mucosa [11-15].

Liver abnormalities are common extraintestinal manifestations of celiac disease. Isolated hypertransaminasemia, with mild or nonspecific histologic changes in the liver biopsy, also known as celiac hepatitis, is the most frequent presentation of liver injury in celiac disease [7]. More and more data suggest that women with celiac disease have a decreased fertility span due to late menarche and early menopause $[8,9,13]$. This case report supports once again that the gluten-free diet is mandatory all life. When this diet is neglected or avoided long term complications of celiac disease arise. One of the most fearsome complications of this disease that affects mainly the women is infertility of unknown origin. It is very important to recognize this association because most of the cases have very few clinical symptoms or only extra intestinal manifestations. Because there are no precise guidelines for the screening of women with celiac disease, the attention must be channeled on the identification of every potential case [9]. What's so particular about this case is that the patient had increased aminotransferase levels, a finding in $20 \%$ of cases [7], late onset of the disease, and fertility disorders associated (two miscariages, irregular period, tardive menarche).

This patient has many risk factors that could recomand screening for celiac disease: recurrent miscarriage, the late appearance of the first menstrual cycle (14 years old), amenorrhea, irregular period, unexplained iron deficiency anemia and persistent elevations of serum transaminases. However until the occurrence of specific clinical manifestations of celiac disease (dehydration, abdominal pain on palpation spontaneous and diffuse, sensation of bloating, nausea and vomiting) ithas not been investigated for this pathology. Increasingly more cases of celiac disease are silent forms. Index of suspicion against a potential case must therefore be very high. Although there are no precise guidelines for the screening of certain female patients with infertility, mixt anemia, elevated trasnsaminases and chronic diarheea, the careful identification of some potential cases is followed up by a quick success quantified as normalization of biochemical tests, weight gain and fertility recovery.

\section{Conclusions}

The mass screening in patient populations is not yet recommended by any medical practice guideline. It places great emphasis on identifying punctualy each case. This can only be done by educating health professionals involved in the evaluation of women with fertility disorders, unexplained iron deficiency anemia and persistent elevations of serum transaminases.

\section{References}

1. DENNIS MD, KELLY CP, SCHUPPAN D. Celiac disease: epidemiology, pathogenesis, diagnosis, and nutritional management. Nutr Clin Care. 2005 Apr-Jun; 8(2): p. 54-69.

2. NEDELCUTA, R.M., CALIN, G., BALEANU, V.D., DAVITOIU, D.V., VOICULESCU, D.I., MIREA, C.S., TENEA COJAN, T.S. , SOCEA, B., ALEXANDRU, D.O., CLENCIU, D., GHEORMAN, V., UDRISTOIU, I., CALBOREAN, V., CIORA, C.A. Anorexia, a First Sign of Diagnosis in Severe Pediatric Disorders. Rev. Chim. (Bucharest), 70, no. 5, 2019, p. 1698-1702.

3. GREEN PHR, STAVROPOULOS SN, PANAGI SG, GOLDSTEIN SL, MCMAHON DJ, ABSAN H, NEUGUT Al. Characteristics of adult celiac disease in the USA: results of a national survey. Am J Gastroenterol. 2001Jan; 96(1): p.126-131.

4. STANESCU, G.L., NEDELCUTA, R.M., DOP, D., DIACONU, R., CALIN, G., NICULESCU, E.C., GHEONEA, C., STANESCU, R., ANGHELINA, L., STANESCU, M.R. Brain abscess of unknown etiology in a 2-year-old child: a case report. Rom J Morphol Embryol 2015, 56(3). p. 12011204.

5. GREEN PH, JABRI B. Coeliac disease.Review. Lancet. 2003 Aug 2; 362(9381):383-91

6. SONI S, BADAW J. Celiac disease and its effect on human reproduction: a review. Reprod Med. 2010 Jan-Feb; 55(1-2):3-8.y SZ. 7. CASELLA G, ANTONELLI E, DI BELLA C, VILLANACCI V, FANINI L, BALDINI V, BASSOTTI G. Prevalence and causes of abnormal liver function in patients with coeliac disease.. Liver Int. 2013 Aug; 33(7): p.1128-31. doi: 10.1111/liv.12178. Epub 2013 Apr 21.

8. SONI S, BADAW J. Celiac disease and its effect on human reproduction: a review. Reprod Med. 2010 JanFeb; 55(1-2):3-8.y SZ. 
9. CIORA. C., DICULESCU. M. Fertility disorders associated to coeliac disease-retrospective study. Research and Science Today 2(8)/2014 , 231-238.

10. MARTINELLI. D., FORTUNATO. F., TAFURI. S., CINZIA A GERMINARIO. Reproductive life disorders in Italian celiac women. A case-control study BMC Gastroenterol 2010; 10:89.

11. CLENCIU, D., TENEA COJAN, T.S., DIJ MARESCU, A.L., ENE , C.G., DAVITOIU, D.V., BALEANU, V.D., CIORA, C.A., SOCEA, B., VOICULESCU, D.I., NEDELCUTA R.M., CALBOREAN, V., GHEORMAN, V., VLADU,I.M. Rev.Chim. (Bucharest), 70, no.4, 2019, p. 1434-1438.

12.NEDELCUTA, R., BALEANU, V.D., CIORA, C., CALIN, G., STANESCU, M.R. , DAVITOIU, D.V., TENEA-COJAN, T.S., SOCEA, B., VOICULESCU, D.I., ALEXANDRU, D.O., STANESCU, R., Rev. Chim. (Bucharest), 70, no.5, 2019, p.1859-1862.
13.GHEORMAN, V., DINESCU, V.C., CRICIOTOIU, O., STANCA, D., CALBOREAN, V., MITA, A., MISCOCI, A., DAVITOIU, D.V., BALEANU, V.D., NEDELCUTA, R.M., DINESCU, S.N., DIJ MARESCU, A.L., VOICULESCU, D.I., UDRISTOIU, I., Rev. Chim. (Bucharest), 70, no. 4, 2019, p.1406-1410.

14.NEDELCUTA, R., POPESCU, M., CALIN, G. Digestive Manifestations in Wilms' Tumor. NEUROGASTRO 2017 - MEETING OF THE ROMANIAN SOCIETY OF NEUROGASTROENTEROLOGY WITH ROME IV REGIONAL CENTRAL EAST EUROPEAN MEETING. 2017, p. 200-204.

15.UNSW ORTH DJ, LOCK FJ, HARVEY RF. Iron-deficiency anaemia in premenopausal women. Lancet. 1999; 353:1100.

Manuscript received: 28.05 .2019 